\title{
Detection of Circulating Tumor Cells Using Three-dimensional and Conditionally Reprogrammed Culture Methods
}

\author{
박천강 $\cdot$ 정영주 $^{2} \cdot$ 박성환 $^{2} \cdot$ 김대동 $^{3} \cdot$ 전창호 $^{1}$ \\ Cheongang Park, M.D. ${ }^{1}$, Young-Ju Jeong, M.D. ${ }^{2}$, Sung-Hwan Park, M.D. ${ }^{2}$, Dae-Dong Kim, M.D. ${ }^{3}$, Chang-Ho Jeon, M.D. ${ }^{1}$ \\ 대구가톨릭대학교 의과대학 진단검사의학과 ${ }^{1} \cdot$ 외과 ${ }^{2}$, 연세대학교 의과대학 외과 ${ }^{3}$ \\ Departments of Laboratory Medicine ${ }^{1}$ and Surgery², Medical School, Daegu Catholic University, Daegu; Department of Surgery ${ }^{3}$, Yonsei \\ University College of Medicine, Seoul, Korea
}

Background: Circulating tumor cells (CTCS) are rare in the circulation of patients with tumors and are very difficult to detect. In this study, we cultured CTCs in a three-dimensionally reprogrammed condition using the peripheral blood of patients with cancer.

Methods: We evaluated the sensitivity of a three-dimensional (3D) conditionally reprogrammed cell (CRC) culture method using SNU-484 gastric cancer cells. From April 2017 to January 2018, blood was collected from 30 patients diagnosed with colorectal or breast cancer at the Daegu Catholic University Medical Center. After lysis of the red blood cells, the blood samples were centrifuged to isolate the mononuclear cells. We used Matrigel to create 3D conditions and reprogrammed the isolated cells using a Rho-kinase inhibitor and J2 feeder cells. After 30 days of culture, the cells were collected and RNA was extracted and amplified for the expression of GAPD, hTERT, and MAGE Al-6 using real-time PCR.

Results: The SNU-484 cells were cultured from three cells using the 3D CRC culture method. The cultured blood samples showed some cells or few colonies. The positive rates of $h$ TERT and MAGE AI- 6 mRNA were $50 \%$ and $30 \%$, respectively. The positive rates of both mRNAs were $60 \%$ and $20 \%$, respectively. MAGE and both mRNAs showed significantly increased odds ratios at the tumor, nodes, and metastases (TNM), N, and M stages in all subjects.

Conclusions: As $60 \%$ of CTCs were detected in the blood of 30 patients with cancer, the 3D CRC culture method was very effective for CTC culture.

Key Words: Neoplastic cells, Circulating, Breast cancer, Colorectal cancer, Culture

\section{INTRODUCTION}

Circulating tumor cells (CTCs) were first reported by Thomas Ashworth in 1869 [1] as a small number of tumor cells found in

Corresponding author: Chang-Ho Jeon, M.D., Ph.D.

(iD https://orcid.org/0000-0002-7450-7117

Department of Laboratory Medicine, Daegu Catholic University Medical Center, 33 Duryugongwon-ro 17-gil, Nam-gu, Daegu 42472, Korea

Tel: +82-53-650-4140, Fax: +82-53-650-8672, E-mail: chjeon@cu.ac.kr

Received: June 16, 2021

Revision received: July 29, 2021

Accepted: August 2, 2021

This article is available from https://www.labmedonline.org (C) 2021, Laboratory Medicine Online

(a) This is an Open Access article distributed under the terms of the Creative Commons Attribution Non-Commercial License (https://creativecommons.org/licenses/by-nc/4.0/) which permits unrestricted non-commercial use, distribution, and reproduction in any medium, provided the original work is properly cited. the blood of patients with tumors. Several studies have shown that CTCs play an important role in tumor metastasis through epithelial-mesenchymal transition [2] or tumor stem cells [3], and the analysis of molecular biological features by detecting CTCs is important for the diagnosis and prognosis of various tumor diseases [4]. These advantages have led to the concept of 'liquid biopsy' [5] to diagnose tumors by detecting CTCs, plasma-free DNA, and exosomes in the blood.

CTCs are present in trace amounts in the blood [6], are physically and immunologically removed from the circulation [7], and have a short half-life of 1-2.4 hours [8]; therefore, it is not easy to detect CTCs in the blood. To overcome these limitations, many separation methods have been developed based on the characteristics of CTCs. Biophysical separation methods utilize the size of CTCs [9] and the difference in the rate of movement in the elec- 
tric field [10]. Immunological separation methods use monoclonal antibodies against epithelial cell adhesion molecule (EpCAM) [11] or tumor cell-specific antigens [12].

There have been many attempts to cultivate isolated CTCs [13, 14], but the isolation process is difficult and shows a low positive rate of $10-20 \%$. To increase the success rate of CTC culture, we have attempted to culture tumor cells in the blood using the conditionally reprogrammed cell (CRC) culture method $[15,16]$. CRC culture is a method in which normal and tumor cells of the epithelial lineage are immortalized when the feeder cells and the Rho-kinase inhibitor (Y-27632) are used together to activate intracellular telomerase and regulate the cell cycle by suppressing the p16/Rb pathway [17]. Unlike cell immortalization by viral oncogenic mRNA transduction, the reprogrammed cell population maintains a normal karyotype and the original phenotype [18]. The CTC culture-positive rates obtained in a previous study using the CRC culture method were 33.3\% for breast cancer and 16.1\% for colorectal cancer $[15,16]$.

To further increase the CTC detection rate, this study intends to detect CTCs using a three-dimensional (3D) CRC culture technique using Matrigel. Matrigel is a reconstructed basement membrane matrix from mouse Engelbreth-Holm-Swarm (EHS) sarcoma [19], used for 3D culture. It contains components, such as collagen and laminin, as well as various growth factors secreted from the extracellular matrix [19], which promote the growth of tumor cells and stimulate the invasion of tumor cells in vitro [20].

\section{MATERIALS AND METHODS}

\section{Sensitivity of 3D CRC culture method}

To evaluate the sensitivity of the 3D CRC culture method, we used SNU-484 gastric cancer cells obtained from the Korean Cell Line Bank (KCLB, Seoul, Korea). A six-well plate was coated with $400 \mu \mathrm{L}$ of Matrigel (Corning, Bedford, MA, USA) and the SNU-484 cells were inoculated at concentrations of 1, 3, 6, 13, 25, and 100 cells and then incubated for 4 weeks with the conditioned $\mathrm{F}$ media [17]. After measuring the number of 100 SNU-484 cells using a cell counter EVE (NanoEnTek, Seoul, Korea), the number of cells was adjusted by a 2 -fold serial dilution. After 4 weeks, we confirmed the culture of SNU-484 cells by observing colony formation under a microscope. This experiment was repeated four times.

\section{Patients and samples}

From April 2017 to January 2018, using cell-free DNA BCT bottles (Streck, Omaha, NE, USA), 6 mL of blood samples were collected from patients (with informed consent) diagnosed with colorectal or breast cancer at the Daegu Catholic University Medical Center. Patients with anemia were excluded (males and females with hemoglobin less than $10 \mathrm{~g} / \mathrm{dL}$ and $8 \mathrm{~g} / \mathrm{dL}$, respectively), and a total of 30 samples were drawn. Blood sampling was performed in the proximal vein of the tumor during surgery in patients who underwent tumor removal surgery or in the peripheral vein in the unoperated group. In addition, information such as sex, age, diagnosis, and cancer stage was collected from the electronic medical records of the hospital. Cancer staging was assessed according to the 7 th edition of the American Joint Committee on Cancer Staging Manual. This study was approved by the institutional review board of Daegu Catholic University Medical Center (CR-17-051-R).

\section{3D CTC culture method}

\section{1) Mononuclear cell collection}

The venous blood collected from the patients was centrifuged at $300 \times \mathrm{g}$ for 20 minutes. at room temperature ( 22 to $24^{\circ} \mathrm{C}$ ) to remove plasma components. Then, $6 \mathrm{~mL}$ of RBC lysis buffer (Roche Diagnostics GmbH, Mannheim, Germany) was added to remove the red blood cells, and the mixture was rolled at room temperature for 15 minutes. The mixture was centrifuged at $350 \times \mathrm{g}$ for 10 minutes at room temperature, the supernatant was removed, and the remaining cell layer was used for culturing.

\section{2) Cell lines}

Swiss 3T3 mouse fibroblasts (J2 strain, obtained from the Georgetown University Medical Center) were used as feeder cells. The SNU-484 cell line was purchased from KCLB and used as a positive control in mRNA real-time PCR.

\section{3) Preparation of conditioned F media}

F media from DMEM media supplemented with fetal bovine serum, glutamine, penicillin/streptomycin, Ham's F12 nutrient mixture, hydrocortisone, epidermal growth factor, insulin, cholera toxin, fungizone, and gentamycin (all from Thermo Scientific, Waltham, MA, USA) was used for culturing J2 fibroblasts. The cultured J2 cells were separated from the culture dish using trypsin- 
EDTA, irradiated with 30 Gy of gamma rays (Gammacell 3000 Elan; MDS Nordion, Ottawa, Canada), and then plated again in 30 $\mathrm{mL}$ of $\mathrm{F}$ medium. The F medium with irradiated J2 cells was collected 3 days later. Three volumes of the obtained supernatant were mixed with one volume of fresh $\mathrm{F}$ medium, and $5 \mu \mathrm{mol} / \mathrm{L}$ Y-27632 (ENZO Life Sciences, Farmingdale, NY, USA) was added to prepare conditioned $\mathrm{F}$ medium for culturing the CTCs.

\section{4) 3D CTC culture using conditioned F media}

For the 3D culture, $500 \mu \mathrm{L}$ of Matrigel Matrix was coated on a $35 \mathrm{~mm}$ Petri dish (Sarstedt, Nümbrecht, Germany) according to the manufacturer's instructions (Thin Gel). The coated dish was inoculated with a mononuclear component containing isolated CTCs and cultured in $3 \mathrm{~mL}$ of conditioned $\mathrm{F}$ medium for 1 month at $37^{\circ} \mathrm{C}$ in a $5 \% \mathrm{CO}_{2}$ environment. During the incubation period, cell growth was observed using a phase-contrast inverted microscope (Eclipse Ti-U; Nikon, Tokyo, Japan) and photographed. After the culture was completed, the cells were separated from the culture dish using 10 units of Dispase (Corning) and then used for detection.

\section{CTC detection with real-time PCR}

Cells isolated from Matrigel were centrifuged at 1,000 $\times \mathrm{g}$ for 5 minutes to obtain cell pellets, and RNA was extracted using TRIzol reagent (Invitrogen; Thermo Scientific). The extracted RNA was reverse transcribed using the ImProm-II Reverse Transcription System (Promega Corporation, Madison, WI, USA) to obtain cDNA. Melanoma-associated antigen (MAGE) A1-6, human telomerase reverse transcriptase ( $(T E R T)$, and glyceraldehyde 3-phosphate dehydrogenase $(G A P D H)$ mRNA were de- tected using real-time PCR and a LightCycler 480 (Roche Diagnostics $\mathrm{GmbH})$. The bTERT and MAGE A1-6 mRNAs were amplified using real-time nested PCR and a LightCycler 480 SYBR Green I Master (Roche Diagnostics $\mathrm{GmbH}$ ), but the cycles of PCR were different. We interpreted the PCR products as positive results using fluorescent signals and melting temperature analysis. The primers used for each polymerization reaction and amplification process are listed in Table 1.

\section{Statistical analysis}

The results were analyzed using SPSS Statistics 20 (International Business Machines Co., Armonk, NY, USA), and Fisher's exact test and logistic regression analysis were used to compare the positive rates of $h T E R T$ and MAGE A1-6 real-time PCR between cancer stages.

\section{RESULTS}

\section{Sensitivity of 3D CRC culture method}

The SNU-484 cell line was cultured when 13 or more cells were added; 75\% with six cells, 50\% with three cells, and no culture with one cell (Table 2). The SNU-484 cells were cultured from three cells using the 3D CRC culture method.

\section{CTC culture with $3 D$ CRC culture}

Within 1 week of culture, all specimens showed cell aggregates; and after 4 weeks, all specimens showed some cells, cell aggregates, or small colonies under a microscope. Fig. 1A, B show a colony of well grown colorectal and breast cancers, respectively, imaged using phase-contrast microscopy. Colorectal tumor cells

Table 1. Primer sequence for each mRNA, product base pair, and PCR process

\begin{tabular}{|c|c|c|c|}
\hline mRNA & Primer sequence & Product (bp) & PCR process \\
\hline \multirow[t]{2}{*}{ GAPDH } & OF 5'-TCG GAG TCA ACG GAT TTG GTC GTA-3' & 320 & $95^{\circ} \mathrm{C} 5 \mathrm{~s}, 59^{\circ} \mathrm{C} 5 \mathrm{~s}, 72^{\circ} \mathrm{C} 18 \mathrm{~s}, 33$ cycles \\
\hline & OR 5'-CAA ATG AGC CCC AGC CT CTC CA-3' & & \\
\hline \multirow[t]{4}{*}{ hTERT } & OF 5'-CGG GCT GCT CCT GCG TाT GGT G-3’' & 311 & $95^{\circ} \mathrm{C} 5 \mathrm{~s}, 68^{\circ} \mathrm{C} 5 \mathrm{~s}, 72^{\circ} \mathrm{C} 16 \mathrm{~s}, 25$ cycles \\
\hline & OR 5'-AGC CGC GGT TGA AGG TGA GAC TGG-3' & & \\
\hline & IF 5'-TCA CCT CAC CCA CGC GAA AAC CT-3' & 152 & $95^{\circ} \mathrm{C} 5 \mathrm{~s}, 66^{\circ} \mathrm{C} 5 \mathrm{~s}, 72^{\circ} \mathrm{C} 10 \mathrm{~s}, 25$ cycles \\
\hline & IR 5'-CGT GGG CCG GCA TCT GAA CAA A-3' & & \\
\hline \multirow[t]{4}{*}{ MAGEA1-6 } & OF 5'-CTG AAG GAG AAG ATC TGC C-3' & 465 & $95^{\circ} \mathrm{C} 5 \mathrm{~s}, 60^{\circ} \mathrm{C} 5 \mathrm{~s}, 72^{\circ} \mathrm{C} 25 \mathrm{~s}, 30$ cycles \\
\hline & OR 5'-CCA GCA Tा CTG CCT TTG TGA-3' & & \\
\hline & IF 5'-AAG GAG AAG ATC TGC CAG TG-3' & 262 & $95^{\circ} \mathrm{C} 5 \mathrm{~s}, 62^{\circ} \mathrm{C} 5 \mathrm{~s}, 72^{\circ} \mathrm{C} 12 \mathrm{~s}, 25$ cycles \\
\hline & IR 5'-GAG GCT CCC TGA GGA CTC T-3' & & \\
\hline
\end{tabular}

Abbreviations: GAPDH, glyceraldehyde 3-phosphate dehydrogenase; $h T E R T$, human telomerase reverse transcriptase; MAGE, melanoma-associated antigen; OF, outer forward; $O R$, outer reverse; IF: inner forward; IR, inner reverse. 

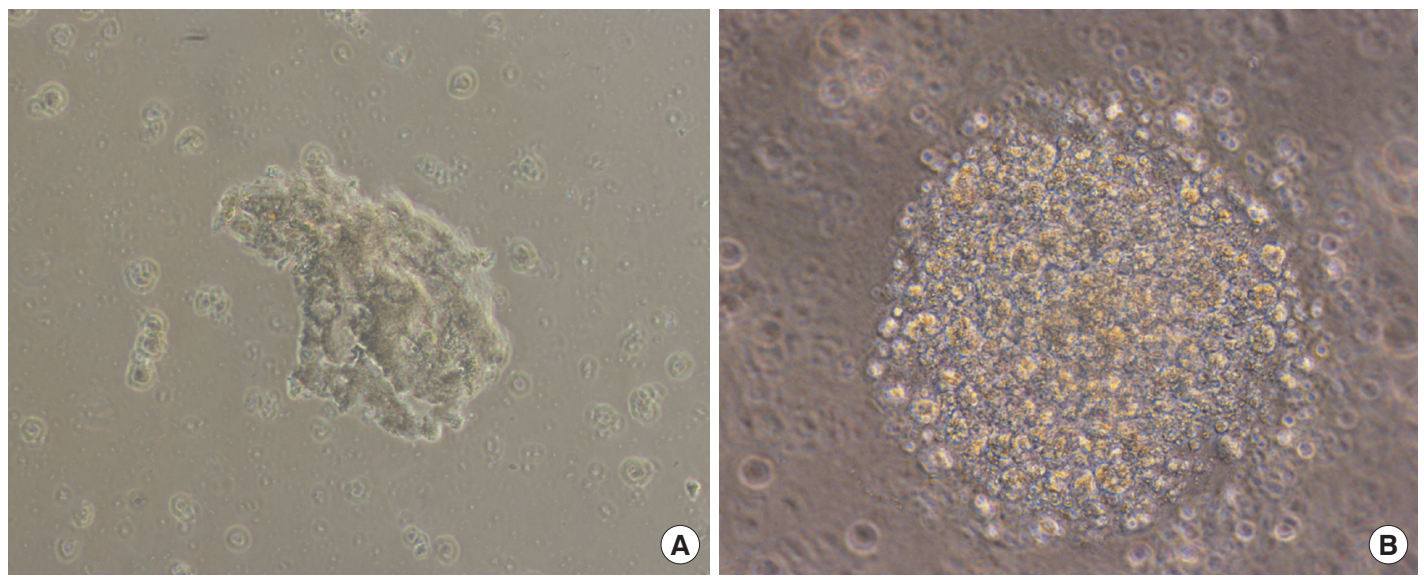

Fig. 1. (A) Cultured cells from a patient with colorectal cancer, captured on day 18 of culture, at $300 \times$ magnification. (B) Cultured cells from a patient with breast cancer, captured on day 15 of culture, at 300x magnification. Colorectal tumor cells formed large undifferentiated aggregates while breast tumor cells formed a large sphere.

Table 2. Sensitivity of three-dimensional CRC culture method

\begin{tabular}{lcccc}
\hline Cell line & Cell count & Matrigel $(\mu \mathrm{L})$ & Number & Positive rates $(\%)$ \\
\hline SNU-484 & 100 & 400 & 4 & 100 \\
SNU-484 & 25 & 400 & 4 & 100 \\
SNU-484 & 13 & 400 & 4 & 100 \\
SNU-484 & 6 & 400 & 4 & 75 \\
SNU-484 & 3 & 400 & 4 & 50 \\
SNU-484 & 1 & 400 & 4 & 0 \\
\hline
\end{tabular}

formed large undifferentiated aggregates, whereas breast tumor cells formed large spheres

\section{Real-time PCR of CTC culture}

Table 3 shows the tumor staging and PCR results for patients with breast cancer. Using RNA extracted from the cultured cells, GAPDH mRNA was positive in all patients, bTERT mRNA in 25\% (2/8), and MAGE A1-6 mRNA in $12.5 \%$ (1/8). None of the mRNAs were positive for both the mRNAs, and three (37.5\%) were positive for either mRNA. Most patients with breast cancer were in cancer stage I or lower.

Table 4 shows the tumor staging and PCR results for the CRC tumor group. GAPDH mRNA was positive in all patients, $b T E R T$ mRNA in 59.1\% (13/22), and MAGE A1-6 mRNA in 36.4\% (8/22). Six (27.3\%) were positive for both the mRNAs, and 15 (68.2\%) were positive for either mRNA. In patients with colorectal cancer, patients with stage II or lower showed significant differences in both real-time PCR positive rates compared to patients with stage III or higher $(P<0.05)$.

The total positive rates in the patients with breast and colorectal
Table 3. Demographic information and PCR results of patients with breast cancer

\begin{tabular}{|c|c|c|c|c|c|c|c|c|c|}
\hline Sex & Age & Stage & T & $\mathrm{N}$ & M & hTERT & MAGE & $\begin{array}{c}\text { hTERT } \\
\text { and } \\
\text { MAGE }\end{array}$ & $\begin{array}{c}\text { hTERT or } \\
\text { MAGE }\end{array}$ \\
\hline $\mathrm{F}$ & 78 & 0 & 0 & 0 & 0 & - & - & - & - \\
\hline $\mathrm{F}$ & 55 & 0 & 0 & 0 & 0 & - & - & - & - \\
\hline $\mathrm{F}$ & 45 & la & 1 & 0 & 0 & - & - & - & - \\
\hline $\mathrm{F}$ & 50 & la & 1 & 0 & 0 & - & - & - & - \\
\hline $\mathrm{F}$ & 42 & la & 1 & 0 & 0 & - & - & - & - \\
\hline $\mathrm{F}$ & 53 & la & 1 & 0 & 0 & + & - & - & + \\
\hline $\mathrm{F}$ & 50 & Ila & 1 & 1 & 0 & + & - & - & + \\
\hline $\mathrm{F}$ & 50 & IIlc & 1 & 3 & 0 & - & + & - & + \\
\hline \multicolumn{6}{|c|}{ Positive rate $(\mathrm{N}=8)$} & $25 \%$ & $12.50 \%$ & 0 & $37.50 \%$ \\
\hline
\end{tabular}

GAPDH results are omitted.

Abbreviations: GAPDH, glyceraldehyde 3-phosphate dehydrogenase; hTERT, human telomerase reverse transcriptase; MAGE, melanoma-associated antigen.

cancers were as follows: hTERT mRNA in 50\% (15/30) and MAGE A1-6 mRNA in 30\% (9/30). Six (20\%) were positive for both the mRNAs, and 18 (60\%) were positive for either mRNA.

\section{Odds ratio of the cancer stage of patients with PCR results}

Significant associations were found between the cancer stage of patients and the PCR results of the cultured cells. Both the mRNAs (MAGE and hTERT) showed significantly increased odds ratios at the TNM, N, and M stages in all subjects. In patients with breast cancer, analysis was not possible due to the small number of subjects; and in patients with colorectal cancer, these were significant at the $\mathrm{M}$ stage $(P<0.05$, Table 5$)$. 
Table 4. Demographic information and PCR results of patients with colorectal cancer

\begin{tabular}{lccccccccc}
\hline Sex & Age & $\begin{array}{c}\text { TNM } \\
\text { Stage }\end{array}$ & T & N & M & hTERT & MAGE & $\begin{array}{c}\text { hTERT } \\
\text { and } \\
\text { MAGE }\end{array}$ & $\begin{array}{c}\text { hTERT } \\
\text { or }\end{array}$ \\
\hline MAGE
\end{tabular}

*Significant difference between the two subgroups $(P<0.05)$.

Abbreviations: hTERT, human telomerase reverse transcriptase; MAGE, melanomaassociated antigen.

\section{DISCUSSION}

Detection of CTCs in the blood has been investigated using various methods based on antibodies, transcripts, or proteins [21, 22]. Recently, many researchers have utilized cell-free DNA (cfDNA) instead of CTCs [23-25]. In some solid tumors, cfDNA has produced promising results [26]. However, this approach is limited because cfDNA yields the same information regarding mutations and epigenetic modifications as the tumor tissue without providing any information about protein and RNA transcription profiles of the tumor phenotype [27]. As CTCs can provide all information about tumor cells, if the low culture-positive rate can be increased, the CTC culture method would be the most suitable method for studying tumor progression and metastasis.

To efficiently separate CTCs, we used the CD45 depletion method [28], MetaCell [29], and RBC lysis buffer. In our experience, the CD45 depletion method required a lot of time, and the MetaCell method did not separate CTCs well depending on the sample, therefore, we used the RBC lysis method. For the successive culture of CTCs, blood collection tubes and prompt processing of blood specimens are important. Rodríguez-Lee et al. [30] showed that overall cell retention was optimal in cfDNA tubes at 24 hours. Therefore, we collected blood specimens with Streck cfDNA tubes and processed the CRC culture within 24 hours. To determine whether the cultured cells were cancer cells, we as-

Table 5. Odds ratio of the cancer stage of patients with PCR positive results

\begin{tabular}{|c|c|c|c|c|c|c|c|c|}
\hline \multirow{2}{*}{ PCR } & \multicolumn{2}{|c|}{ TNM stage (>III vs. <II) } & \multicolumn{2}{|c|}{ Tstage ( > 3 vs. $<2$ ) } & \multicolumn{2}{|c|}{ N stage (> 1 vs. 0 ) } & \multicolumn{2}{|c|}{ M stage (>1 vs. 0) } \\
\hline & $\mathrm{OR}(95 \% \mathrm{Cl})$ & $P$-value & $\mathrm{OR}(95 \% \mathrm{Cl})$ & $P$-value & $\mathrm{OR}(95 \% \mathrm{Cl})$ & $P$-value & OR $(95 \% \mathrm{Cl})$ & $P$-value \\
\hline \multicolumn{9}{|c|}{ Total $(\mathrm{N}=30)$} \\
\hline hTERT & $2.25(0.52-9.7)$ & 0.277 & $1.33(0.3-5.91)$ & 0.705 & $2.25(0.52-9.7)$ & 0.277 & $5.09(0.5-52.29)$ & 0.171 \\
\hline MAGE & $7.56(1.5-38.15)$ & $0.014^{*}$ & $0.9(0.37-2.21)$ & 0.819 & $7.56(1.5-38.15)$ & $0.014^{*}$ & $16(1.45-176.5)$ & $0.024^{*}$ \\
\hline Both & $5.44(1.14-25.95)$ & $0.033^{*}$ & $0.46(0.18-1.21)$ & 0.117 & $5.44(1.14-25.95)$ & $0.033^{*}$ & 46 (3.33-634.9) & $0.004^{*}$ \\
\hline Either & $2.98(0.68-13.17)$ & 0.149 & $2.6(0.56-2.02)$ & 0.221 & $2.98(0.68-13.17)$ & 0.149 & $3.14(0.31-32.28)$ & 0.335 \\
\hline \multicolumn{9}{|c|}{$\operatorname{BRC}(\mathrm{N}=8)$} \\
\hline hTERT & $5(0.15-66.59)$ & 0.368 & NA & & $5(0.15-66.59)$ & 0.368 & NA & \\
\hline MAGE & NA & & NA & & NA & & NA & \\
\hline Both & NA & & NA & & NA & & NA & \\
\hline Either & NA & & NA & & NA & & NA & \\
\hline \multicolumn{9}{|c|}{$\mathrm{CRC}(\mathrm{N}=22)$} \\
\hline hTERT & $1.28(0.23-7.19)$ & 0.779 & $1.28(0.23-7.19)$ & 0.779 & $1.28(0.23-7.19)$ & 0.779 & $3.56(0.33-38.78)$ & 0.298 \\
\hline MAGE & 9.33 (0.89-97.62) & 0.062 & $1.6(0.52-4.89)$ & 0.410 & 9.33 (0.89-97.62) & 0.062 & $13(1.11-152.4)$ & $0.041^{*}$ \\
\hline Both & 4.59 (0.76-27.62) & 0.096 & $0.86(0.29-2.55)$ & 0.782 & 4.59 (0.76-27.62) & 0.096 & $30(2.14-421.1)$ & $0.012^{*}$ \\
\hline Either & $1.12(0.18-6.93)$ & 0.899 & $2.67(0.42-6.83)$ & 0.297 & $1.12(0.18-6.93)$ & 0.899 & $2.18(0.2-24.21)$ & 0.525 \\
\hline
\end{tabular}

*Significant correlation. $P<0.05$.

Abbreviations: BRC, breast cancer; CRC, colorectal cancer; hTERT, human telomerase reverse transcriptase; $M A G E$, melanoma-associated antigen; OR, odds ratio; $\mathrm{Cl}$, confidence interval; NA, not applicable. 
sayed for MAGE and $h T E R T$ mRNA. In our previous study [15, 16, 28], these two genes were also used to identify tumor cells in CTC cultures. Although hTERT mRNA might be expressed in the cells of the CRC culture [17], its expression could differentiate human cancer cells from mouse fibroblast $\mathrm{J} 2$ cells due to its positive and negative expression, respectively.

The sensitivity of the CRC culture method was also evaluated. As the cell concentration was measured using the dilution method, the number of cells used for the sensitivity measurement may not be accurate. To overcome this limitation, the sensitivity evaluation was repeated four times. In a previous study [16], the minimum number of SNU-484 cells capable of forming a colony was six. Liu et al. [17] reported a minimum number of four (primary keratinocytes) and two (cervical cancer cells). At present, the minimum number is three. However, in Liu's study, there was no description of the number of repetitions and how to measure the number of injected cells, therefore, direct comparison of results may be difficult. Our previous studies used a three-dimensional (3D) CRC technique, whereas this study used a 3D CRC technique. These results suggest that 3D CRC culture enhanced the ability to detect CTCs.

With 3D CRC culture, cell aggregates or colonies were observed in all 30 cultured specimens, but not all the cultured cells were CTCs when PCR results were considered. As shown in Table 3, the positive rate of CTC in patients with breast cancer was 37.5\%. In a study by Zhang et al. [13], in which CTCs were first cultured in vitro, three out of 15 (20\%) patients with invasive breast cancer were positive for culture. In a study by Yu et al. [14], six metastatic cancers out of 36 breast cancer samples (16.7\%) were cultured; however, in a previous study by the author [15] using the 2D CRC culture method showed a positive rate of $33.3 \%$, indicating a positive rate similar to that in this study. As shown in Table 4, the positive rate of CTCs in patients with colorectal cancer was $68.2 \%$. To detect CTCs in patients with colorectal cancer, a detection method using surface antigen or cfDNA was mainly used rather than culture [31-34]. The CTC detection rate varied from 18.9-91.3\% [31-34], and was proportional to the cancer stage, and the DNA detection method showed a higher positivity than the surface antigen detection method. In a study by Cayrefourcq [31] in patients with metastatic colorectal cancer, the positive rates of surface antigen detection and culture were $70.4 \%$ and $2.8 \%$, respectively. Our study [16] using a 2D CRC culture showed a posi- tive rate of $16.1 \%$. Therefore, the $2 \mathrm{D}$ CRC culture method is very useful for detecting CTCs in patients with CRC. Compared to the 2D culture method, the 3D CRC culture method showed a similar CTC detection rate in breast cancer patients but was very high in colorectal cancer patients. The proportion of patients with breast and colorectal cancers with stage 1 or less was $75.0 \%$ and $17.9 \%$, respectively, which might explain why the effect of the 3D CRC culture method is not prominent in patients with breast cancer with many early stage cancers.

In the association study between cancer stage and real-time PCR results, the results of $M A G E$ and both real-time PCR showed increased odds ratios at the TNM, N, and M stages. In previous studies on CRC culture [15, 16], bTERT showed higher sensitivity than $M A G E$ despite $M A G E$ known to be expressed specifically in tumor cells.

A limitation of this study is that the number of patients with colorectal and breast cancers was not large. The number of patients with colorectal cancer was not sufficient for each stage, therefore, they were grouped into two groups for statistical analysis. The number of patients with breast cancer was particularly small; therefore, statistical analysis was not performed.

The CTC culture method has not been utilized in the clinical field because of its low positive rate; however, this study showed new hopes for 3D CTC culture by showing a CTC detection rate of $68.2 \%$ in patients with colorectal cancer. In future studies, we will confirm the sensitivity of the 3D CRC culture method by supplementing the number of cases and analyzing the characteristics of the tumor from the cultured cells in more detail.

\section{요 약}

배경: 혈중종양세포는 종양환자의 혈액에서 소량으로 존재하여 검출이 매우 어렵다. 본 연구에서는 종양환자에서 말초혈액을 이 용하여 혈중종양세포를 3 차원 재분화 조건하에서 배양하였다.

방법: SNU-484 위암세포주를 사용하여 3차원 재분화 배양법의 민감도를 확인하였다. 2017년 4월부터 2018년 1월까지 대구가톨릭 의료원에서 대장암 및 유방암으로 진단받은 30 명의 혈액을 배양 하였다. 혈액내 적혈구를 용혈 시킨 후 원심 하여 단핵구 세포층을 분리하였다. Matrigel을 사용하여 3차원 배양조건을, Rho-kinase 억제제와 J2 세포주를 이용하여 재분화 조건을 각각 형성하였다. 배양 30 일 후 배양된 세포를 수거하여 RNA를 추출하였고 GAPD, bTERT 및 MAGE A1-6 유전자를 실시간 중합효소연쇄반응으로 
증폭하였다.

결과: SNU-344 세포주를 사용한 3차원 재분화 배양법으로 3개 세 포부터 배양되었다. 말초혈액을 배양하여 세포 응집이나 소수의 세포 집락을 형성하였다. 배양된 세포들의 $b T E R T$ 및 MAGE A1-6 유전자 양성률은 각각 $50 \%$ 및 30\%였다. 두가지 유전자중 한 개 유 전자 및 동시양성률은 각각 $60 \%$ 및 $20 \%$ 였다. MAGE 양성 및 동시 양성은 환자들의 TNM 병기, $\mathrm{N}$ 병기 및 $\mathrm{M}$ 병기에 따라 의미 있는 교차비 증가를 나타내었다.

결론: 30 명의 종양환자의 말초혈액에서 $60 \%$ 의 혈중종양세포 검 출률을 나타내어 3 차원적 재분화 배양법은 혈중종양세포 검출에 매우 유용하였다.

\section{Conflicts of Interest}

None declared.

\section{Acknowledgment}

This study was supported by the Industry Academic Cooperation Foundation of the Daegu Catholic University (201712).

\section{REFERENCES}

1. Ashworth TR. A case of cancer in which cells similar to those in the tumours were seen in the blood after death. Aust Med J 1869;14:146-7.

2. Pecot CV, Bischoff FZ, Mayer JA, Wong KL, Pham T, Bottsford-Miller J, et al. A novel platform for detection of CK+ and CK- CTCs. Cancer Discov 2011;1:580-6.

3. Marrinucci D, Bethel K, Kolatkar A, Luttgen MS, Malchiodi M, Baehring $\mathrm{F}$, et al. Fluid biopsy in patients with metastatic prostate, pancreatic and breast cancers. Phys Biol 2012;9:016003.

4. Haber DA and Velculescu VE. Blood-based analyses of cancer: circulating tumor cells and circulating tumor DNA. Cancer Discov 2014; 4:650-61.

5. Azim HA, Jr., Rothé F, Aura CM, Bavington M, Maetens M, Rouas G, et al. Circulating tumor cells and response to neoadjuvant paclitaxel and HER2-targeted therapy: a sub-study from the NeoALTTO phase III trial. Breast 2013;22:1060-5.

6. Miller MC, Doyle GV, Terstappen LW. Significance of circulating tumor cells detected by the CellSearch System in patients with metastatic breast colorectal and prostate cancer. J Oncol 2010;2010:617421.

7. Kang Y and Pantel K. Tumor cell dissemination: emerging biological insights from animal models and cancer patients. Cancer Cell 2013; 23:573-81.

8. Meng S, Tripathy D, Frenkel EP, Shete S, Naftalis EZ, Huth JF, et al. Circulating tumor cells in patients with breast cancer dormancy. Clin Cancer Res 2004;10:8152-62.

9. Dong Y, Skelley AM, Merdek KD, Sprott KM, Jiang C, Pierceall WE, et al. Microfluidics and circulating tumor cells. J Mol Diagn 2013;15:14957.

10. Gupta V, Jafferii I, Garza M, Melnikova VO, Hasegawa DK, Pethig R, et al. ApoStream ${ }^{\mathrm{TM}}$, a new dielectrophoretic device for antibody independent isolation and recovery of viable cancer cells from blood. Biomicrofluidics 2012;6:24133.

11. Nagrath S, Sequist LV, Maheswaran S, Bell DW, Irimia D, Ulkus L, et al. Isolation of rare circulating tumour cells in cancer patients by microchip technology. Nature 2007;450:1235-9.

12. Gleghorn JP, Pratt ED, Denning D, Liu H, Bander NH, Tagawa ST, et al. Capture of circulating tumor cells from whole blood of prostate cancer patients using geometrically enhanced differential immunocapture (GEDI) and a prostate-specific antibody. Lab Chip 2010;10:279.

13. Zhang L, Ridgway LD, Wetzel MD, Ngo J, Yin W, Kumar D, et al. The identification and characterization of breast cancer CTCs competent for brain metastasis. Sci Transl Med 2013;5:180ra48.

14. Yu M, Bardia A, Aceto N, Bersani F, Madden MW, Donaldson MC, et al. Ex vivo culture of circulating breast tumor cells for individualized testing of drug susceptibility. Science 2014;345:216-20.

15. Jeong YJ, Park SH, Jeon CH. Detection of circulating tumor cells in patients with breast cancer using the conditionally reprogrammed cell culture method and reverse transcription PCR of hTERT and MAGE A1 6. Oncol Lett 2020:20:78.

16. Yang CS, Kim IH, Chae HD, Kim DD, Jeon CH. Detection of circulating gastrointestinal cancer cells in conditionally reprogrammed cell culture. In Vivo 2021;35:1515-20.

17. Liu X, Ory V, Chapman S, Yuan H, Albanese C, Kallakury B, et al. ROCK inhibitor and feeder cells induce the conditional reprogramming of epithelial cells. Am J Pathol 2012;180:599-607.

18. Suprynowicz FA, Upadhyay G, Krawczyk E, Kramer SC, Hebert JD, Liu $\mathrm{X}$, et al. Conditionally reprogrammed cells represent a stem-like state of adult epithelial cells. Proc Natl Acad Sci U S A 2012;109:2003540.

19. Benton G, Kleinman HK, George J, Arnaoutova I. Multiple uses of basement membrane-like matrix (BME/Matrigel) in vitro and in vivo 
with cancer cells. Int J Cancer 2011;128:1751-7.

20. Liu $X$ and Wu X. Utilizing matrigel transwell invasion assay to detect and enumerate circulating tumor cells. Methods Mol Biol 2017;1634: $277-82$.

21. Ferreira MM, Ramani VC, Jeffrey SS. Circulating tumor cell technologies. Mol Oncol 2016;10:374-94.

22. Ilie M, Szafer-Glusman E, Hofman V, Long-Mira E, Suttmann R, Darbonne W, et al. Expression of MET in circulating tumor cells correlates with expression in tumor tissue from advanced-stage lung cancer patients. Oncotarget 2017;8:26112-21.

23. Masuda T, Hayashi N, Iguchi T, Ito S, Eguchi H, Mimori K. Clinical and biological significance of circulating tumor cells in cancer. Mol Oncol 2016;10:408-17.

24. Szilágyi M, Pös O, Márton É, Buglyó G, Soltész B, Keserü J, et al. Circulating cell-free nucleic acids: Main characteristics and clinical application. Int J Mol Sci 2020;21:6827.

25. Stewart CM and Tsui DWY. Circulating cell-free DNA for non-invasive cancer management. Cancer Genet 2018;228-9:169-79.

26. Jiang T, Ren S, Zhou C. Role of circulating-tumor DNA analysis in nonsmall cell lung cancer. Lung Cancer 2015;90:128-34.

27. Brock G, Castellanos-Rizaldos E, Hu L, Coticchia C, Skog J. Liquid biopsy for cancer screening, patient stratification and monitoring. Transl Cancer Res 2015;4:280-90

28. Kim DD, Yang CS, Chae HD, Kwak SG, Jeon CH. Melanoma antigenencoding gene family member A1-6 and hTERT in the detection of cir- culating tumor cells following CD45- depletion and RNA extraction. Oncol Lett 2017;14:837-43.

29. Bobek V, Gurlich R, Eliasova P, Kolostova K. Circulating tumor cells in pancreatic cancer patients: Enrichment and cultivation. World J Gastroenterol 2014;20:17163-70.

30. Rodríguez-Lee M, Kolatkar A, McCormick M, Dago AD, Kendall J, Carlsson NA, et al. Effect of blood collection tube type and time to processing on the enumeration and high-content characterization of circulating tumor cells using the high-definition single-cell assay. Arch Pathol Lab Med 2018;142:198-207.

31. Cayrefourcq L, Mazard T, Joosse S, Solassol J, Ramos J, Assenat E, et al. Establishment and characterization of a cell line from human circulating colon cancer cells. Cancer Res 2015;75:892-901.

32. Kaifi JT, Kunkel M, Dicker DT, Joude J, Allen JE, Das A, et al. Circulating tumor cell levels are elevated in colorectal cancer patients with high tumor burden in the liver. Cancer Biol Ther 2015;16:690-8.

33. Takeda K, Yamada T, Takahashi G, Iwai T, Ueda K, Kuriyama S, et al. Analysis of colorectal cancer-related mutations by liquid biopsy: Utility of circulating cell-free DNA and circulating tumor cells. Cancer Sci 2019;110:3497-509.

34. Bidard FC, Kiavue N, Ychou M, Cabel L, Stern MH, Madic J, et al. Circulating tumor cells and circulating tumor DNA detection in potentially resectable metastatic colorectal cancer: a prospective ancillary study to the unicancer prodige-14 trial. Cells 2019;8:516. 